\title{
Students and Money Management Behavior of a Malaysian Public University*
}

\author{
Mohd Danial ZULFARIS**, Hasri MUSTAFA***, Norlida MAHUSSIN****, \\ Md. Kausar ALAM $* * * * *$, Zaidi Mat DAUD $* * * * * *$
}

Received: January 01, 2020 Revised: February 02, 2020 Accepted: February 06, 2020.

\begin{abstract}
This study aims to investigate whether financial literacy, parental socialization, peer influence and self-control have a significant impact on money management among students of a Malaysian public university. In most settings, the studies on the determinants of personal saving behavior among university students focus on personality factors, attitudes toward money and possessions, and financial knowledge as predictors of money management behavior. Primary data are collected using a self-administered questionnaire with the samples comprised 186 students. The findings show that all the financial literacy and parent socialization have a positive relationship with money management; meanwhile, peer influences and self-control have a negative relationship with money management. This is because the majority of students admit they cannot control their self in managing their money. In this study, parent socialization has a significant relationship with money management which signifies that parents are playing essential roles in ensuring their children to establish money management. In practical, this study can contribute to the parents in providing their children to foster sound money management. Besides, Perbadanan Tabung Pendidikan Tinggi Nasional (National Higher Education Fund Corporation) PTPTN should monitor the loan, and management process and arrange motivational program so that students can more focus on the educational expense.
\end{abstract}

Keywords: Financial Literacy, Parental Socialization, Peer Influence, Self-control.

JEL Classification Code: M1; M5; M42; M42; M48.

\section{Introduction}

\footnotetext{
*The authors gratefully acknowledge the financial support of the Research University Grant Scheme of Unievrsiti Putra Malaysia, vote number, 13001.

${ }^{* *}$ First Author. Department of Accounting and Finance, Faculty of Economics and Management, Universiti Putra Malaysia (UPM), Malaysia. Email: 173567@student.upm.edu.my

${ }^{* * *}$ Corresponding Author. Associate Professor, Department of Accounting and Finance, Faculty of Economics and Management, Universiti Putra Malaysia (UPM), Malaysia. [Postal Address: Room\# E205, Faculty of Economics and Management, Universiti Putra Malaysia (UPM), Serdang, Selangor, 43400, Malaysia] Email: hasyie@upm.edu.my

****Lecturer, Faculty of Science and Technology, Universiti Sains Malaysia, Bandar Baru Nilai, Negeri Sembilan, Malaysia. Email: norlida@usim.edu.my

${ }^{* * * * *} \mathrm{PhD}$, Department of Accounting and Finance, Faculty of Economics and Management, Universiti Putra Malaysia (UPM), Malaysia. Email: kausarflorence@gmail.com

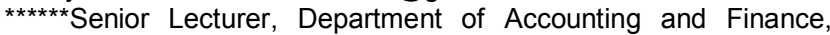
Faculty of Economics and Management, Universiti Putra Malaysia (UPM), Malaysia. Email: mrzaidi@upm.edu.my
}

Money is an asset that plays an important role in our daily lives, especially in the current economic uncertainty.

Without money, many necessities of life cannot be fulfilled correctly. There is saying money is not everything, but in reality, almost all the affairs of life require money. It is not only important to those who are already working but also to students and therefore money must be managed properly. According to Barr and McClellan (2018), life and current financial needs in higher education institutions are very demanding. Student applications for financial aid increased as the economy suffered.

The need for students to manage money wisely is, therefore critical. The federal government, the parents, the higher learning institutions, and the students are benefits from the wise money management behavior. Images related to saving behavior among university students shape society's impressions about the future leaders' commitment and responsibility to public money (Kezar, Chambers, \&

() Copyright: The Author(s)

This is an Open Access article distributed under the terms of the Creative Commons Attribution NonCommercial License (https://creativecommons.org/licenses/by-nc/4.0/) which permits unrestricted noncommercial use, distribution, and reproduction in any medium, provided the original work is properly cited. 
Burkhardt, 2015). There must be a system of financial planning for university students. Students of higher education are mostly young people and always strive to equip themselves with skills to face the challenges outside of campus life. According to Mohamed (1993), economics and finance is a field that examines the activities of individuals or communities in their daily lives, which deals with how to use limited resources in the best way to meet the various requirements too much. In Malaysia, most of the students studying in higher education institutions get PTPTN loan which stands for Perbadanan Tabung Pendidikan Tinggi Nasional (National Higher Education Fund Corporation) is a study loan provided by the government for Malaysian students at tertiary education. Since the primary use of PTPTN loan is only for education, careful planning to ensure the money is used in the best way is necessary. The failure to use the loan in the right way causes the students to end up with other borrowing and financial problems.

In Malaysia, according to Jamal, Ramlan, Karim, and Osman (2015), there were about 280,428 individuals reported to have enrolled in financial and debt management program since the establishment of The Malaysian Credit Counseling and Debt Management Agency (AKPK) in 2006. From all the cases reported, " 44 percent of the individuals involved in this financial counseling program belonged to the 30-40 age groups" (p. 111).

Literature observes the student of PTPTN loan prefer to overspend their education loans on luxury goods (e.g. Selvaratnam, Tan, Abu Bakar, Endut, \& Fatimah, 2013; Naradin, Ismail, Harun, \& Khamis, 2018). University students like to spend money mostly for the appearance of branded items and food in high-class restaurants. Without proper money management plan, to keep this way of offcampus-style living, many students have to do a part-time job for extra money. In a long time, this affects students' attention to the lessons in the class and students' enough time to revise and complete the assigned tasks.

Hence, this study suggests a study on financial management among university students. The research focuses on management in spending PTPTN loan by students of a Malaysian public university. The study is interesting since ninety percent of the core subjects taking by these students are related to accounting, finance, principle management and investment. The study, therefore, provides insights as to whether: 1) financial literacy, 2) parental socialization, 3) peer influence and 4) self-control are factors that affect money management of students.

The following section discusses the literature review and hypothesis development. It then follows with a detailed discussion of the process of data collection and construction of variables. Next, discussion and analysis of the data are carried out. Finally, conclusion, limitation and recommendation for further study are presented.

\section{Literature Review and Conceptual Framework}

The National Higher Education Fund Corporation (PTPTN) was established on 1st July 1997 under the National Higher Education Fund Corporation Act 1997. The vision for the National Higher Education Fund Corporation is to ensure that no student should be denied access to higher education due to financial reasons. The corporation is responsible for managing the loan financing of higher education to the students of public and private higher education in Malaysia. PTPTN provides loans according to the type of course, institution and other necessities. For private universities, the loan is higher than public universities. Methods of payment and the total payment also vary according to the amount of the loan made. There are some cases whereby loans are converted to scholarships for excellent students.

Reports by New Straits Times (2019) shows that university students spent their money on basic necessities such as food, books and other personal expenses. The rise in the cost of living and books may affect the sustainability of cash flow among students. Kim and Yang (2020) found that external (such as hardware, performance, software, design, and price) and internal selection factors (brand awareness, corporate trust, store trust, and product reputation) had a positive influence on repurchase intentions, and in particular, appealing to internal and external selection factors in order to promote repurchase intention.

The report added that socioeconomics and demographic factors also play roles in students' spending behavior. Jung (2020) outlined that the social network and social norms have significantly a statistical effect with personal happiness, but social trust does not have significant influence. Besides, students from a lower-income background most likely to have financial problems throughout study periods. D'Silva (2012) sees student spending habits become more common nowadays for a designing brand on clothes and accessories as well as on entertainment.

According to Falahati, Paim, Ismail, and Masud (2011), students need to be equipped with financial management and knowledge to help them match their needs with available resources. With the knowledge, students can outline financial objectives, activities and goals. For example, Currie, Dethier, and Togo (2003) consider debt management skills as beneficial for commercial purposes, accountability and sustainability. Ergun (2018) believes the financial education is vital and can influence the general commercial awareness, which could help students handle 
their finance better and improve financial wellbeing. Most, in general, agree that financial skills concerning future planning and the preparation of budget are the advantages to students. Students from Accounting and Finance background have been found to have more significant general financial awareness. They are also presenting in financial planning, short courses, and seminars more frequent than other university students. Involvement of the students in social institutions such as mosques and churches may help students to increase their financial knowledge (Sabri \& Falahati, 2012).

Sam, Caroline, and Rosle (2010) observe parents can influence individual's financial management behavior. Parents can become a role model for their children in managing their finance. Sabri and Falahati (2012) view parents as primary socialization agents who have a positive effect on financial literacy level. They found students with earlier consumer experiences during childhood in family financial matters; their financial literacy is enhanced significantly. Basically, parents are able to enhance their children financial literacy which indirectly improved their financial management. In summary, creating awareness among parents, family, and students about the importance of practicing good financial habits may enhance the financial management skills and knowledge.

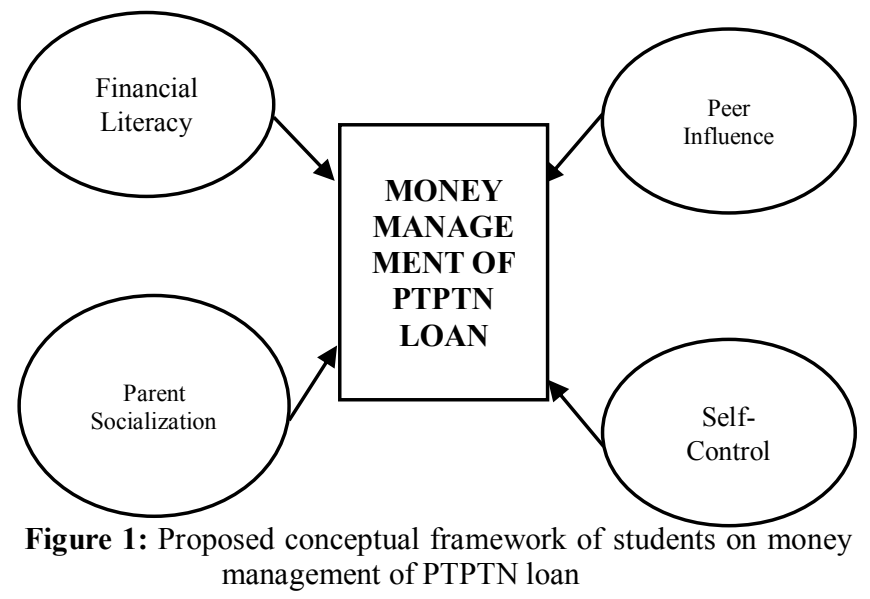

According to Jorgensen and Savla (2010), parents are responsible for their children university education fees and hence, are having more control than their university peers as influenced factors. But, since Geer (2012) urges spending is the hardest thing to do for students, and most students are living far away from their parents, should any spending related behavior happened, peers can be responsible for being associated. Although Geer's analysis (2012; also Shim, Serido, Tang, \& Card, 2015) does not show significant result on peers influenced in financial knowledge, attitudes or financial behaviors, it does help to show the influence of peers somehow may grow if the influence of parents diminishes (Garrison \& Gutter, 2010; Gutter, Garrison, \& Copur, 2010; Lusardi, Mitchell, \& Curto, 2010).

Shim et al. (2010) describe that people among youth are becoming impulsive spenders as they have more pocket money, credit cards or other family members' credit card. Although most of them are smart and independent, they do not understand the value of money. University students also spend their discretionary income to achieve their wants rather than saving their money to pursue their studies. According to Baumeister (2002), adequate self-control depends on at least three significant ingredients such as standards, the monitoring process, and the operational capacity to alter one's behavior. The key important aspect of self-control is the capacity to resist temptations, especially those relevant to impulsive expenditures (ibid). Haws, Bearden, and Nenkov (2012) view self-control as an individual difference and consider "individual who is generally high in self-control might have difficulties when it comes to curtailing spending" and "someone who is generally average in self-control could be an extremely self-controlled health fanatic" (p. 697).

Figure 1 summarizes all the above four variables, which are the factors that might influence money management of PTPTN loan among students. The elements could, in turn, contribute to the design of effective methods for money management spending. The next section discusses hypotheses development based on literature.

\section{Hypotheses Development and Research Method}

The relationship between financial literacy and money management is essential in determining the management of money and economic problems (Sabri, Cook, \& Gudmunson, 2012). In general, students should learn about knowledge and skills in personal finance to understand their financial situation. Nevertheless, Fernandes, Lynch, and Netemeyer (2014) found financial literacy produces little significant on financial experience that is presumed to cause economic behavior. Thus, the following hypothesis is proposed.

H1: There is a significant influence of financial literacy to money management

Jamal et al. (2015) assert that parents are highly influential in shaping children's financial management behavior. In technical, parents' function as a role model for their children. Falahati and Paim (2011) regard parents or family as socialization agents. As for socialization agents, they may show a contrasting view in financial management 
since in some cases, the family may spend more money and have a lower level of saving (Sabri \& Falahati, 2012). As such, the following hypothesis is proposed.

H2: There is a significant influence of parental socialization to money management

According to Geer (2012), spending is the hardest thing to do for students who have money constraint. However, peers have influenced the financial knowledge, attitudes and behaviors of their students. Peer attachment may encourage or discourage money spending, depending on what types of company they keep. Since peers can promote many things including academic cheating (Gentina, Tang, $\& \mathrm{Gu}, 2017)$, it is not impossible for them to also improve proper money management (Gentina, Tang, \& Gu, 2018). Thus, the following hypothesis is proposed.

H3: There is a significant influence of peer influence on money management

Self-control is mentioned as an essential determinant of an individual's saving and spending, both in economic and economic psychological literature. Nepomuceno and Laroche (2017) find that self-control allows people to suppress stereotypes and prejudices and by enhancing selfcontrol, the intention to resist consumption increases, especially for those who believe that self-control is a source of happiness later on. In general, literature generally agrees that restraint can define as the capacity to alter or override dominant response tendencies and to regulate behavior, thoughts, and emotions of individuals (De Ridder \& Lensvelt-Mulders, 2018). As such, the following hypothesis is proposed.

H4: There is a significant influence of self-control to money management

This study is done among students majoring in Economics and Management, in a Malaysian public university. The data is collected via a survey questionnaire. The questionnaire consists of demographic profile, spending pattern and money management sections duplicated in Wankanfad (2012) Delafrooz and Paim (2011), and Sabri and MacDonald (2010). A five-point Likert type scale ranging from (1) 'strongly agree' to (5) 'strongly disagree' have been used in the instrument. The asked questions were related to how much students spent in a month, save their money last semester and do the budget when after receiving the PTPTN loan. We empirically test the hypotheses using the following regression model:

$$
\text { MonMgt }_{i}=\alpha+\beta 1 \text { FinLit }_{i}+\beta 2 \text { ParSoc }_{i}+
$$

$\beta 3$ Peer $_{i}+\beta 4$ SelfCon $_{i}+\mu_{i}$

Where, MonMgt $_{i}$ is Money management among students, FinLit ${ }_{i}$ is financial literacy, ParSoc $_{i}$ is parent socialize, $\mathrm{Peer}_{i}$ is peer influence and $\mathrm{SelfCon}_{i}$ is selfcontrol for student $i$. The study predicts $\beta 1, \beta 2, \beta 2$ and $\beta 4$ with positive correlation. The target population for the study is 240 students of a Malaysian public university. The total population selected from three programs which are Bachelor in Accountancy, Bachelor in Business Administration and Bachelor in Economic. Based on 'Table Krejcie and Morgan 1970', the minimum of sample size for a total population of 240 respondents is 148 respondents. Nevertheless, a total of 186 students are the surveyed respondents. The larger the sample, the higher the confidence levels in the estimate.

\section{Research Findings}

Table 1 summarizes the basic statistics on PTPTN Loan, Gender, program, age, race, current CGPA, marital status, and money management of the respondents.

Table 1: Distribution of respondents $(n=186)$

\begin{tabular}{|c|c|c|}
\hline & & Valid percent (\%) \\
\hline PTPTN Loan & Received & 73.1 \\
\hline & No & 26.9 \\
\hline Gender & Male & 37.6 \\
\hline Programme & Accounting & 62.4 \\
\hline & Economics & 59.7 \\
\hline & Business Administration & 17.7 \\
\hline Age group & 18 and below & 22.6 \\
\hline & $19-20$ & 2.7 \\
\hline & $21-22$ & 16.7 \\
\hline & 23 and above & 48.9 \\
\hline Race group & Malay & 31.7 \\
\hline & Chinese & 78.0 \\
\hline & Indian & 16.1 \\
\hline & Others & 2.2 \\
\hline Current CGPA & $\geq 3.5$ & 3.8 \\
\hline & $3.0 \leq$ CGPA $<3.5$ & 47.8 \\
\hline & $<3.0$ & 12.4 \\
\hline Marital status & Marriage & 5.4 \\
\hline
\end{tabular}

Out of 186 respondents, only 136 have received PTPTN loan. From the figure, $62.4 \%$ of the respondents are female, $37.6 \%$ are male. Accounting, business administration and economics students represent $59.7 \%, 22.6 \%$ and $17.7 \%$ of 
total respondents respectively. Out of the percentage, $48.9 \%$ of the respondents fall into the group of 21-22 years old, followed by $31.7 \%$ age group of 23 years old and above, $16.7 \%$ between 19 to 20 years old, and $2.7 \%$ of 18 years old and below. $78 \%$ of the respondents are Malay, $16.1 \%$ Chinese, $2.2 \%$ Indian, and $3.8 \%$ other races. $47.8 \%$ of the respondents received CGPA between $3.0 \leq \mathrm{CGPA}<3.5,39.8 \%$ with CGPA $\geq 3.5$, and $12.4 \%$ with CGPA $<3.0$. Majority of the respondents are single, only $5.4 \%$ are married. Finally, $94.9 \%$ of the respondents are categorized as PTPTN loan self-manage, only $4.1 \%$ as parent-manage.

Table 2 shows the Pearson Correlation between variables used in this study. All variables correlate significantly with money management (MonMgt) except self-control (SelfCon). The highest correlation is between money management (MonMgt) and parent socialize (ParSoc) at 0.522 . However, the correlations among other variables are low and below than 0.5 .

Table 2: Correlation matrix of explanatory variables

\begin{tabular}{|c|c|c|c|c|c|}
\hline & MonMgt & FinLit & ParSoc & Peer & SelfCon \\
\hline MonMgt & 1.000 & & & & \\
\hline FinLit & $0.417^{* *}$ & 1.000 & & & \\
\hline ParSoc & $0.522^{* * *}$ & $0.266^{* * *}$ & 1.000 & & \\
\hline Peer & $0.391^{* * *}$ & $0.394^{* * *}$ & $0.499^{* * *}$ & 1.000 & \\
\hline SelfCon & 0.053 & $0.165^{*}$ & $0.178^{*}$ & $0.449 * * *$ & 1.000 \\
\hline
\end{tabular}

Notes: This table presents Pearson Correlation between variables in this study. MonMgt is money management, FinLit ${ }_{i}$ is financial literacy, $\operatorname{ParSoc}_{i}$ is parent socialize, Peer $r_{i}$ is peer influence and SelfCon $_{i}$ is self-control for student $i$. $* * * * *, *$ represent significant level at $1 \%, 5 \%$ and $10 \%$ respectively.

Table 3: Determinants of Money Management among Students

\begin{tabular}{|c|c|c|}
\hline & Coefficient & t-stat \\
\hline FinLit & 0.271 & $3.538^{* * *}$ \\
\hline ParSoc & 0.400 & $5.162^{* * *}$ \\
\hline Peer & 0.166 & $1.891^{*}$ \\
\hline SelfCon & -0.092 & $-1.791^{*}$ \\
\hline Constant & 1.020 & $3.020^{* * *}$ \\
\hline Adjusted R2 & 0.360 & \\
\hline Observation & 186 & \\
\hline
\end{tabular}

Notes: This table presents the determinants of money management among students. The dependent variable is Money Management (MonMgt $t_{i}$ ). FinLit $_{i}$ is financial literacy, ParSoc $_{i}$ is parent socialize, Peer $r_{i}$ is peer influence and $\mathrm{SelfCon}_{i}$ is self-control for student $i . * * * * *, *$ represent significant level at $1 \%, 5 \%$ and $10 \%$ respectively.

Table 3 presents the results for the regression model in equation 1. The result shows financial literature (FinLit) and parent socialize (ParSoc) are positively influence student's money management and highly significant at 1 percent. Peer influence (Peer) has found positively related to student' money management and significant at 10 percent. Though the coefficient for Self-control (SelfCon) is positive, however, the result is not significant. These findings indicate that money management among students is influenced by financial literature, parent socialize and peer influence. Among the three, parent socialize greater impact on student's money management which is in line with Sam et al. (2010), and Sabri and Falahati (2012) findings.

\section{Discussion, Limitation and Recommendation}

There is adequate proof to infer that the related money education has a critical association with sparing conduct of the students $(p<0.05)$. This is supported in Sabri and MacDonald (2010), which uncovered that financial literacy is fundamentally identified with students' positive conduct. Different findings, for example, Delafrooz and Paim (2011) and Hilgert, Hogarth, and Beverly (2003), additionally demonstrated that the budgetary education impacts individual conduct. Hence, students who have a more elevated amount of fiscal proficiency will probably spare as they have the capacity to recognize the significance and learning of reserve funds.

The finding demonstrates that parental socialization and sparing conduct are absolutely related $(\mathrm{p}<0.05)$. The outcome acquired is concurred with the studies of Shim, Barber, Card, Xiao, and Serido (2010) which reasoned that parental financial behaviors affect the sparing conduct of young adults. Furthermore, investigations of Brown and Taylor (2016) and Otto (2013) also supported the above hypothesis which is there is a significant impact over the saving behavior of their children. Therefore, parental socialization is the thing that cannot be avoided in controlling and encouraging their children to save their money.

Nevertheless, there is no significant influence of peers to money management of students ( $>0.05)$. Danes and Hira (1987) found that being married created a necessity for learning financial issues that many single students may not confront (e.g., health and life insurance, budgeting, investing, and wills). Furthermore, married students have to discuss the issue of money and work out how each thinks money should be handled. In this study, where the majority of the respondents are not married, peers are therefore fundamentally weak variable. There is also no significant influence of self-control to money management of final year students. This is because the majority of students admit they cannot control their self in managing their money.

Overall, this study suggests bigger specimen size in the future so to be an illustrative study with the populace mean (Saunders, Lewis, \& Thornhill, 2009), with more precise 
conduct of students (see Lim, Sia, \& Gan, 2011). Therefore, the authority should concern of the moral issues of the student to spend their loan money in study issues rather than buying costly or branding items. Whilst, the study of Purwono, Nugroho, and Mubin (2019) found that the imposition of the collateral to the debtor has an essential role in avoiding moral hazard. The study acknowledges, based on the findings, the importance to involve intervening variables to better clarify the connection between students and money management behavior, such as culture, life pressures, and religious factors. It could be students with an abnormal state of monetary proficiency. In this case, researchers recommend utilizing qualitative methods such as personal observation and interview, fieldwork and case study.

\section{References}

Barr, M. J., \& McClellan, G. S. (2018). Budgets and financial management in higher education. Hoboken, NJ: John Wiley $\&$ Sons.

Baumeister, R. F. (2002). Yielding to temptation: Self-control failure, impulsive purchasing, and consumer behavior. Journal of Consumer Research, 28(4), 670-676.

Brown, S., \& Taylor, K. (2016). Early influences on saving behavior: Analysis of British panel data. Journal of Banking \& Finance, 62, 1-4.

Currie, E., Dethier, J. J., \& Togo, E. (2003). Institutional arrangements for public debt management. Washington, DC: The World Bank.

D'Silva, N. V. (2012). Market research on student spending. Retrieved November 10, 2019 from

www.buzzle.com/articles/market-research-on-studentspending.html

Danes, S. M., \& Hira, T. K. (1987). Money management knowledge of college students. Journal of Student Financial Aid, 17(1), 4-16.

De Ridder, D. T., \& Lensvelt-Mulders, G. (2018). Taking stock of self-control: A meta-analysis of how trait self-control relates to a wide range of behaviors. In Self-Regulation and SelfControl (pp. 221-274). Abingdon, United Kingdom: Routledge.

Delafrooz, N., \& Paim, L. H. (2011). Determinants of saving behavior and financial problem among employees in Malaysia. Australian Journal of Basic and Applied Sciences, 5(7), 222-228.

Ergun, K. (2018). Financial literacy among university students: A study in eight European countries. International Journal of Consumer Studies, 42(1), 9-15.

Falahati, L., Paim, L., Ismail, M., \& Masud, J. (2011). Assessment of university students' financial management skills and educational needs. African Journal of Business Management, 5(15), 6085-6091.

Falahati, L., \& Paim, L. H. (2011). Toward a framework of determinants of financial management and financial problems among university students. Journal of Business Management,
5(22), 9600-9606.

Fernandes, D., Lynch, J. G. Jr., \& Netemeyer, R. G. (2014). Financial literacy, financial education, and downstream financial behaviors. Management Science, 60(8), 1861-1883.

Garrison, S. T., \& Gutter, M. S. (2010). Gender differences in financial socialization and willingness to take financial risks. Journal of Financial Counseling and Planning, 21(2), 60-72.

Geer, C. Y. (2012). Students need money-management lessons too. Retrieved November 10, 2019 from http://online.wsj.com/article/SB100008723963904443181045 77587400019575634.html.

Gentina, E., Tang, T. L. P., \& Gu, Q. (2018). Do parents and peers influence adolescents' monetary intelligence and consumer ethics? French and Chinese adolescents and behavioral economics. Journal of Business Ethics, 151(1), 115-140.

Gentina, E., Tang, T. L. P., \& Gu, Q. (2017). Does bad company corrupt good morals? Social bonding and academic cheating among French and Chinese teens. Journal of Business Ethics, 146(3), 639-667.

Gutter, M. S., Garrison, S., \& Copur, Z. (2010). Social learning opportunities and the financial behaviors of college students. Family and Consumer Sciences Research Journal, 38(4), 387404.

Haws, K. L., Bearden, W. O., \& Nenkov, G. Y. (2012). Consumer spending self-control effectiveness and outcome elaboration prompts. Journal of the Academy of Marketing Science, 40(5), 695-710.

Hilgert, M. A., Hogarth, J. M., \& Beverly S.B. (2003). Household Financial Management: The Connection between Knowledge and Behaviour. Federal Reserve Bulletin, 309-322.

Jamal, A. A. A., Ramlan, W. K., Karim, M. A., \& Osman, Z. (2015). The effects of social influence and financial literacy on savings behavior: A study on students of higher learning institutions in Kota Kinabalu, Sabah. International Journal of Business and Social Science, 6(11), 110-119.

Jorgensen, B. L., \& Savla, J. (2010). Financial literacy of young adults: The importance of parental socialization. Family Relations, 59(4), 465-478.

Jung, M.-H. (2020). The Effect of Social Capital on Personal Happiness: A Focus on Service Industry Employees. Journal of Asian Finance, Economics and Business, 7(1), 291-299. https://doi.org/10.13106/jafeb.2020.vol7.no1.291

Kezar, A., Chambers, A. C., \& Burkhardt, J. C. (Eds.). (2015). Higher education for the public good: Emerging voices from a national movement. Hoboken, NJ: John Wiley \& Sons.

Kim, Y. E., \& Yang, H. C. (2020). The Effects of Perceived Satisfaction Level of High-Involvement Product Choice Attribute of Millennial Generation on Repurchase Intention: Moderating Effect of Gender Difference. Journal of Asian Finance, Economics and Business, 7(1), 131-140. https://doi.org/10.13106/jafeb.2020.vol7.no1.131

Lim, C. S., Sia, B. K., \& Gan, G. J. (2011). The analysis of psychological factors affecting savers in Malaysia. Middle Easter Finance and Economic, 12, 77-85.

Lusardi, A., Mitchell, O. S., \& Curto, V. (2010). Financial literacy among the young. Journal of Consumer Affairs, 44(2), 358380.

Mohamed, M. (1993). Economic Understanding: for those who lead and lead. Kuala Lumpur, Malaysia: Cahaya Pantai (M) 
Sdn. Bhd.

Naradin, D. K., Ismail, F., Harun, N. S., \& Khamis, Z. (2018). Determinants of the Saving Behaviour among Students of UiTM Terengganu. Terengganu International Finance and Economics Journal, 5(1), 31-40.

Nepomuceno, M. V., \& Laroche, M. (2017). When materialists intend to resist consumption: The moderating role of selfcontrol and long-term orientation. Journal of Business Ethics, 143(3), 467-483.

Otto, A. M. C. (2013). Saving in childhood and adolescence: Insights from developmental psychology. Economics of Education Review, 33, 8-18.

Purwono, R., Nugroho, R. Y. Y., \& Mubin, M. K. (2019). Response on New Credit Program in Indonesia: An Asymmetric Information Perspective. Journal of Asian Finance, Economics and Business, 6(2), 33-44.

https://doi.org/10.13106/jafeb.2019.vol6.no2.33

Sabri, M. F., \& Falahati, L. (2012). Estimating a model of subjective financial well-being among college students. International Journal of Humanities and Social Science, 2(18), 191-199.

Sabri, M. F., Cook, C. C., \& Gudmunson, C. G., (2012). Financial well-being of Malaysian college students. Asian Education and Development Studies, 1(2), 153-170.

Sabri, M. F., \& MacDonald, M. (2010). Savings behaviour and financial problems among college students: The role of financial literacy in Malaysia. Cross-Cultural Communication, 6(3), 103-110.

Sam. Y. T., Caroline. G., \& Rosle., A. M., (2010). Financial behaviour among undergraduate student with and without financial education: A case among University Malaysia Sabah Undergrades. Jilid, (1), 210-224.

Saunders, M., Lewis, P., \& Thornhill, A. (2009). Research methods for business students (4th ed.). Harlow, England: Prentice Hall.

Selvaratnam, D., Tan, K., Abu Bakar, N., Endut, W., \& Fatimah, R. (2013). Awareness and Socialisation of Consumer Rights among UKM Students. SSRN Electronic Journal, 1-19. http://dx.doi.org/10.2139/ssrn.2211324

Shim, S., Barber, B., Card, N., Xiao, J. J., \& Serido, J. (2010). Financial socialization of first-year college students: The roles of parents, work and education. Journal of Youth and Adolescence, 39(12), 1457-1470.

Shim, S., Serido, J., Tang, C., \& Card, N. (2015). Socialization processes and pathways to healthy financial development for emerging young adults. Journal of Applied Developmental Psychology, 38, 29-38.

Wankanfad. (2012). Use of PTPTN loan among second year students in the Faculty of Manufacturing Engineering and Technology Management. Retrieved November 10, 2019 from http://wankanfad.wikispaces.com/ questionnaire 